\title{
CLDN18 Gene Product
}

National Cancer Institute

\section{Source}

National Cancer Institute. CLDN18 Gene Product. NCI Thesaurus. Code C150410.

A protein encoded by the CLDN18 gene. 